\title{
Analysis of Factors Affecting Commitment and Ability of Families to Early Detection in Stunting
}

\author{
Nursalam Nursalam ${ }^{1 *} \oplus$, Sri Utami ${ }^{2} \oplus$, Rekawati Susilaningrum ${ }^{3} \odot$ \\ ${ }^{1 *}$ Faculty of Nursing, Universitas Airlangga, Surabaya, Indonesia \\ ${ }^{2,3}$ Polytechnic Health of Surabaya, Surabaya, Indonesia
}

\begin{abstract}
Background: Stunting is a public health problem in the world, stunting will have an impact on the growth and development of children. The first 1000 days of life are important to prevent stunting, this is a period when the child's body system experiences physical growth, intelligence, and children's abilities.

Purpose:This study aims to analyze the factors that influence family commitment and ability to detect stunting.

Methods: A cross-sectional study was conducted on 130 respondents in public health center, Surabaya, Indonesia. Data was collected through a questionnaire via Google form, anonymous online research questionnaire was collected through social media, such as Telegram, WhatsApp, Facebook which was conducted from June to September 2020. Data were analyzed using SPSS software version 21 with multivariate logistic regression.

Results: The dominant factor affecting the commitment in early detection of stunting was community resources $(p=0.006$; $\mathrm{Cl} 95 \%=0.888-4.272)$. Supporting $(p=0.000 ; \mathrm{Cl} 95 \%=1.757-79.610)$, empowering $(p=0.000 ; \mathrm{Cl}$ $95 \%=0.603-18.363)$ and enabling $(p=0.000 ; \mathrm{Cl} 95 \%=0.395-4.869)$ were dominant factors that affected the ability to detect early stunting.

Conclusion: The behavior of commitment and willingness in early detection of stunting in children is an important role that every parent must have with full support from the family. The main factor influencing family commitment is community resources and the main factor is the willingness of early detection to support, empower and enable families to provide care for their children.
\end{abstract}

Keywords: family ability; family commitment; early detection; stunting.

\section{Introduction}

The growth and development of children is still one of the problems that need to be considered by all countries, especially countries with lower middle income (Lestari, Fujiati, Keumalasari, \& Daulay, 2018). Child development including physical, emotional and social development is very important, growth and development problem can cause a child to experience delays and become stunted (Curry, 2018; Goldin \& Papaioannou, 2003). The condition of stunting in children, which is the main factor, is the condition of the family environment and parenting styles (Fajrianti, Yunitasari, \& Pradanie, 2020; Situmeang, Etti Sudaryati, \& Jumirah, 2020). Stunting is a problem that can be prevented if periodic health checks for pregnant women are carried out (Pertiwi, Lestari, \& Ulfiana, 2019; Utami, Setiawan, \& Fitriyani, 2019), so that if it is known that there is a risk of stunting, action can be immediately given (Primasari \& Keliat, 2020). The ability of families to detect stunting early is still very lacking (Pradnyawati, Kartinawati, \& Juwati, 2019; Primasari \& Keliat, 2020), babies are considered to just not want to eat and that is a natural activity, so when they are brought to health services, babies have experienced more serious growth and development delays (Curry, 2018). The problem of stunting must be resolved with the cooperation of parents, families, health workers, the community and the government, because the commitment to preventing and overcoming stunting is the 
key to reducing the high stunting rate in Indonesia (Utami, Susilaningrum, \& Nursalam, 2019; Utami, Susilaningrum, Taufiqurrahman, \& Nursalam, 2019). Until now, there are not many studies that discuss the factors that influence commitment and early detection ability, especially on factors related to interpersonal and health promotion.

The incidence of stunting in Indonesia is still very high. Based on anthropometric measurements of infants such as weight based on age, nutritional status and height, Indonesia is a country with the fifth rank of stunting cases that have not been resolved in the world. (Leroy \& Frongillo, 2019; Ryadinency \& Patmawati, 2020). The incidence of stunting in 2017 in the world was $22.2 \%$ or around 150.8 million children under five in the world were stunted. It illustrates that more than half of the world's stunted children come from Asia (55\%) while more than a third (39\%) live in Africa. (Alkaff, Flynn, Sukmajaya, \& Salamah, 2020; Soekatri, Sandjaja, \& Syauqy, 2020). The incidence of stunting in children under five in Asia is 83.6 million, the highest proportion is from South Asia (58.7\%) and the lowest proportion is in Central Asia (0.9\%) (Utami et al., 2019; Utami, Susilaningrum, Taufiqurrahman, et al., 2019). Stunting prevalence data collected by the World Health Organization (WHO) shows that Indonesia is one of the third countries with the highest prevalence in the Southeast Asia / South-East Asia Regional region (Beal, Tumilowicz, Sutrisna, Izwardy, \& Neufeld, 2018; Langi, 2020). The average prevalence of stunting under five in Indonesia in $2005-2017$ is $36.4 \%$. According to the 2013 Basic Health Research, the national prevalence of stunting reached 37.2 percent, an increase from 2010, which was $35.6 \%$ and 2007 , which was $36.8 \%$. This means that about 8.9 million Indonesian children, or one in three Indonesian children, suffer from suboptimal growth. The prevalence of stunting in Indonesia is higher than other countries in Southeast Asia, such as Myanmar at $35 \%$, Vietnam at $23 \%$, and Thailand at $16 \%$. This condition is still very high, even though one of the points for sustainable development goals (SDGs) is to try to improve the health of mothers and children (Utami, Susilaningrum, Taufiqurrahman, \& Nursalam, 2019).

Indonesia is a country with a fairly high prevalence of stunting compared to other middleincome countries (Beal et al., 2018; Rizal \& van Doorslaer, 2019). Toddlers who are stunted will experience a slowdown in the process of growth and development of intelligence, so that they are not able to be maximized, are more susceptible to disease and are at risk of looking different compared to other children of the same age (Titaley, Ariawan, Hapsari, Muasyaroh, \& Dibley, 2019). The importance of the first 1000 days of life is crucial in preventing stunting, this is a time when the child's body system experiences physical growth, intelligence, and ability. So far, the program that has been carried out by the government through the National Team for the Acceleration of Poverty Reduction has determined
100 priority districts / cities for stunting reduction (Susilaningrum, Utami, Nursalam, \& Tristiana, 2018). Priority areas or areas that are the main locus of stunting intervention are areas that have a high prevalence rate of stunting compared to other areas (Izza, Purnomo, \& Mahmudah, 2019). The aim of this program is to reduce the stunting rate so that it does not increase. The government also cooperates with the public health sector, public health center to participate in the prevention, early detection and promotion of stunting health. Therefore, this study aims to analyze the factors that influence family commitment and ability to detect stunting.

\section{Methods}

\section{Research Design}

This study was quantitative research design with cross-sectional survey.

\section{Participant Setting}

The population of the study were all families with children aged 0 - 72 months in the area of the Public Health Center in Surabaya City. A total of 130 family respondents were selected to be the research sample through simple random sampling technique. The criteria of the sample were 1) families with husband and wife who have children aged $0-72$ months; 2) following the health check-up regularly; 3) able to use a smartphone and have internet access; 4) able to speak Indonesian; 5) willing to be a respondent. The exclusion criteria were families with health problems and mental health disorders.

\section{Procedures}

The pandemic condition in the city of Surabaya with the implementation of social distancing made direct data collection impossible. Therefore, the survey of data collection on respondents was carried out online through Google. Questionnaires were distributed online using a Google form, online research questionnaire collection was anonymously collected through social media, such as Telegram, WhatsApp, Facebook which was conducted in June - September 2020. Respondents filled out questionnaires voluntarily, not through coercion and anonymous questionnaires. All respondents were given informed consent online beforehand, willing respondents were allowed to continue filling out the questionnaire and for respondents who did not wish to continue, there was no coercion element. The online questionnaire consists of a demographic data questionnaire, commitment and family abilities, family connectedness, community resources, competing role demand, empowering, enabling and supporting. The final results of the study will be linked to the commitment variable and the ability to detect early child growth and development.

\section{Variable definition}

Respondents will fill out questionnaires online 
Original Article

Analysis of Factors Affecting Commitment

Table 1. The Demographic Characteristics of Respondents $(n=130)$

\begin{tabular}{lcc}
\multicolumn{1}{c}{ Variable } & $\mathbf{n}$ & $\%$ \\
\hline Mother's Age & 2 & \\
$<20$ years & 2 & 1.5 \\
$20-30$ years & 98 & 75.4 \\
$>35$ years & 30 & 23.1
\end{tabular}

Mother's Education

$46 \quad 35.4$

Middle Education $\quad 68 \quad 52.3$

$\begin{array}{lll}\text { High Education } & 16 & 12.3\end{array}$

$\begin{array}{lcc}\text { Mother's Job } & & \\ \text { Housewives } & 106 & 81.5 \\ \text { Civil Servant } & 7 & 5.4 \\ \text { Privat Employee } & 17 & 13.1\end{array}$

Mother's Income

$\begin{array}{lll}\text { Under Minimum Regional } & 124 & 95.4\end{array}$

$\begin{array}{lll}\text { Same and above Minimum } & 6 & 4.6\end{array}$

Regional

$\begin{array}{lcc}\text { Father's Job } & & \\ \text { Entrepreneur } & 6 & 4.6 \\ \text { Civil Servant } & 104 & 80.6 \\ \text { Private Employee } & 20 & 14.8\end{array}$

Father's Income

Under Minimum Regional $\quad 106 \quad 82.2$

$\begin{array}{lll}\text { Same and above Minimum } & 24 & 17.8\end{array}$

Regional

$\begin{array}{lll}\text { Number of Children } & & \\ \text { One } & 48 & 37.0 \\ \text { Two } & 50 & 38.5 \\ \text { Three } & 32 & 24.5\end{array}$

Last Child's Age

$\begin{array}{lll}1 \text { years } & 32 & 24.6 \\ 2 \text { years } & 26 & 20.0 \\ 3 \text { years } & 72 & 55.4\end{array}$

\begin{tabular}{lcc} 
Healthcare Utility & & \\
Very limited & 1 & 0.8 \\
Sometimes & 6 & 4.6 \\
Often & 6 & 4.6 \\
Always & 117 & 90.0 \\
\hline
\end{tabular}

through surveys of demographic data variables, family connectedness, community resources, competing role demand, empowering, enabling and supporting, commitment and family abilities. The demographic data questionnaire consisted of open-ended questions regarding age, education, occupation of mothers and husbands, income, number of children and visits to public health center. The questionnaire on family connectedness, community resources and competing role demand is a questionnaire with a Likert scale consisting of strongly agree $=4$, agree $=3$, disagree $=2$ and strongly disagree $=1$, with unfavorable questions is the opposite. The questionnaire is a modification of 24 questions with the validity of the questionnaire $0.819-0.936$ and the reliability of 0.866 . The empowering, enabling and supporting questionnaire is a modification of the health promotion model theory which has gone through the validity test with a value of $0.879-0.916$. The questionnaire consists 
Original Article

Nursalam., et al. (2021)

Table 2. The Cross-Tabulation Commitment and Ability of Mother to Detect Stunting in Children $(n=130)$

\begin{tabular}{|c|c|c|c|c|c|c|c|c|}
\hline \multirow[t]{3}{*}{ Variable } & \multicolumn{3}{|c|}{ Commitment } & \multirow[t]{3}{*}{$\mathbf{P}$} & \multicolumn{3}{|c|}{ Ability } & \multirow[t]{3}{*}{$\mathbf{P}$} \\
\hline & Low & $\begin{array}{l}\text { Moder- } \\
\text { ate }\end{array}$ & High & & Low & $\begin{array}{l}\text { Moder- } \\
\text { ate }\end{array}$ & High & \\
\hline & n (\%) & n (\%) & n (\%) & & n (\%) & n (\%) & n (\%) & \\
\hline \multicolumn{9}{|l|}{ Mother's Age } \\
\hline$<20$ years & $0(0.0)$ & $1(0.8)$ & $1(0.8)$ & 0.798 & $1(0.8)$ & - & $1(0.8)$ & 0.104 \\
\hline $20-30$ years & $28(21.5)$ & $45(34.6)$ & $25(19.2)$ & & $9(6.9)$ & $56(43.1)$ & $33(25.4)$ & \\
\hline > 35 years & $8(6.2)$ & $12(9.2)$ & $10(7.7)$ & & $2(1.5)$ & $22(16.9)$ & $6(4.6)$ & \\
\hline \multicolumn{9}{|l|}{$\begin{array}{l}\text { Mother's Edu- } \\
\text { cation }\end{array}$} \\
\hline $\begin{array}{l}\text { Basic Educa- } \\
\text { tion }\end{array}$ & $11(8.5)$ & $23(17.7)$ & $12(9.2)$ & 0.258 & $3(2.3)$ & $32(24.6)$ & $11(8.5)$ & 0.255 \\
\hline $\begin{array}{l}\text { Middle Edu- } \\
\text { cation }\end{array}$ & 19 (14.6) & $32(24.6)$ & $17(13.1)$ & & $7(5.3)$ & $40(30.8)$ & $21(16.2)$ & \\
\hline $\begin{array}{l}\text { High Educa- } \\
\text { tion }\end{array}$ & $6(4.6)$ & $3(2.3)$ & $7(5.4)$ & & $2(1.5)$ & $6(4.6)$ & $8(6.2)$ & \\
\hline \multicolumn{9}{|l|}{ Mother's Job } \\
\hline Housewives & $28(21.5)$ & 50 (38.6) & $28(21.5)$ & 0.758 & $9(6.9)$ & $67(51.5)$ & $30(23.1)$ & 0.642 \\
\hline Civil Servant & $2(1.5)$ & $3(2.4)$ & $2(1.5)$ & & $1(0.8)$ & $3(2.3)$ & $3(2.3)$ & \\
\hline $\begin{array}{l}\text { Privat Em- } \\
\text { ployee }\end{array}$ & $6(4.6)$ & $5(3.8)$ & $6(4.6)$ & & $2(1.5)$ & $8(6.2)$ & $7(5.4)$ & \\
\hline \multicolumn{9}{|l|}{$\begin{array}{l}\text { Mother's } \\
\text { Income }\end{array}$} \\
\hline $\begin{array}{l}\text { Under Mini- } \\
\text { mum Regional }\end{array}$ & $34(26.1)$ & 57 (43.9) & $33(25.4)$ & 0.065 & $11(8.4)$ & $74(56.9)$ & $39(30.0)$ & 0.559 \\
\hline $\begin{array}{l}\text { Same and } \\
\text { above Mini- } \\
\text { mum Regional }\end{array}$ & $2(1.5)$ & $1(0.8)$ & $3(2.3)$ & & $1(0.8)$ & $4(3.1)$ & $1(0.8)$ & \\
\hline \multicolumn{9}{|l|}{ Father's Job } \\
\hline Entrepreneur & $2(2.7)$ & $1(1.4)$ & $4(3.1)$ & $<0.0001$ & - & $2(1.7)$ & $3(2.3)$ & 0.539 \\
\hline Civil Servant & 24 (17.5) & $55(41.6)$ & $25(18.4)$ & & $10(7.8)$ & $62(47.1)$ & $33(23.8)$ & \\
\hline $\begin{array}{l}\text { Privat Em- } \\
\text { ployee }\end{array}$ & $11(8.5)$ & $1(1.4)$ & $7(5.4)$ & & $1(0.9)$ & $14(10.9)$ & $5(3.9)$ & \\
\hline \multicolumn{9}{|l|}{$\begin{array}{l}\text { Father's } \\
\text { Income }\end{array}$} \\
\hline $\begin{array}{l}\text { Under Mini- } \\
\text { mum Regional }\end{array}$ & $29(22.5)$ & $50(38.8)$ & 27 (20.9) & 0.283 & $8(6.2)$ & $66(51.2)$ & $34(24.8)$ & 0.572 \\
\hline $\begin{array}{l}\text { Same and } \\
\text { above Mini- } \\
\text { mum Regional }\end{array}$ & $7(5.4)$ & $7(5.4)$ & $10(7.0)$ & & $3(2.3)$ & $11(9.3)$ & $8(6.2)$ & \\
\hline \multicolumn{9}{|l|}{$\begin{array}{l}\text { Number of } \\
\text { Children }\end{array}$} \\
\hline One & $11(8.5)$ & $20(15.4)$ & $17(13.1)$ & 0.303 & $2(1.5)$ & $29(22.3)$ & $17(13.1)$ & 0.694 \\
\hline Two & $16(12.3)$ & 25 (19.2) & $9(6.9)$ & & $7(5.4)$ & $29(22.3)$ & $14(10.8)$ & \\
\hline Three & $9(6.9)$ & $13(10.0)$ & $10(7.7)$ & & $3(2.3)$ & $20(15.4)$ & $9(6.9)$ & \\
\hline \multicolumn{9}{|l|}{$\begin{array}{l}\text { Last Child's } \\
\text { Age }\end{array}$} \\
\hline 1 years & $11(8.5)$ & 15 (11.5) & $6(4.6)$ & 0.347 & $4(3.1)$ & $23(17.8)$ & $5(3.8)$ & 0.274 \\
\hline 2 years & $6(4.6)$ & $9(6.9)$ & $11(8.5)$ & & $3(2.3)$ & 14 (10.8) & $9(6.9)$ & \\
\hline 3 years & 19 (14.6) & $34(26.2)$ & 19 (14.6) & & $5(3.8)$ & $41(31.5)$ & $26(20.0)$ & \\
\hline
\end{tabular}


Cont. Table 2. The Cross-Tabulation Commitment and Ability of Mother to Detect Stunting in Children $(n=130)$

\begin{tabular}{|c|c|c|c|c|c|c|c|c|}
\hline \multirow[t]{3}{*}{ Variable } & \multicolumn{3}{|c|}{ Commitment } & \multirow[t]{3}{*}{$p$} & \multicolumn{3}{|c|}{ Ability } & \multirow[t]{3}{*}{$\mathbf{p}$} \\
\hline & Low & $\begin{array}{l}\text { Moder- } \\
\text { ate }\end{array}$ & High & & Low & $\begin{array}{l}\text { Moder- } \\
\text { ate }\end{array}$ & High & \\
\hline & n (\%) & n (\%) & n (\%) & & n (\%) & n (\%) & n (\%) & \\
\hline \multicolumn{9}{|l|}{$\begin{array}{l}\text { Healthcare } \\
\text { Utility }\end{array}$} \\
\hline Very limited & $1(0.8)$ & - & - & 0.224 & - & $1(0.8)$ & - & 0.036 \\
\hline Sometimes & $2(1.5)$ & $3(2.3)$ & $1(0.8)$ & & $3(2.3)$ & $2(1.5)$ & $1(0.8)$ & \\
\hline Often & $0(0.0)$ & $2(1.5)$ & $4(3.1)$ & & $0(0.0)$ & $4(3.1)$ & $2(1.5)$ & \\
\hline Always & $33(25.4)$ & $53(40.8)$ & $31(23.8)$ & & $9(6.9)$ & $71(54.6)$ & $37(28.5)$ & \\
\hline \multicolumn{9}{|l|}{$\begin{array}{l}\text { Family Con- } \\
\text { nectedness }\end{array}$} \\
\hline Low & $25(19.2)$ & $5(3.8)$ & $1(0.9)$ & $<0.0001$ & $4(3.1)$ & $21(16.2)$ & $6(4.6)$ & 0.002 \\
\hline Moderate & $11(8.5)$ & $38(29.2)$ & $18(13.8)$ & & $7(5.4)$ & $45(34.6)$ & $15(11.5)$ & \\
\hline High & $0(0.0)$ & $15(11.5)$ & $17(13.1)$ & & $1(0.8)$ & $12(9.2)$ & $19(14.6)$ & \\
\hline \multicolumn{9}{|l|}{$\begin{array}{l}\text { Community } \\
\text { Resources }\end{array}$} \\
\hline Low & $25(19.3)$ & $2(1.5)$ & $2(1.5)$ & $<0.0001$ & $5(3.9)$ & $18(13.8)$ & $6(4.7)$ & $<0.0001$ \\
\hline Moderate & $7(5.4)$ & 41 (31.5) & $8(6.2)$ & & $5(3.9)$ & $42(32.3)$ & $9(6.9)$ & \\
\hline High & $4(3.1)$ & 15 (11.5) & $26(20.0)$ & & $2(1.5)$ & $18(13.8)$ & 25 (19.2) & \\
\hline \multicolumn{9}{|l|}{$\begin{array}{l}\text { Competing } \\
\text { Role Demand }\end{array}$} \\
\hline Low & $1(0.8)$ & $2(1.5)$ & - & 0.706 & $1(0.8)$ & $2(1.6)$ & - & 0.338 \\
\hline Moderate & $23(17.7)$ & $42(32.3)$ & 25 (19.2) & & $6(4.6)$ & $56(43.1)$ & $28(21.5)$ & \\
\hline High & $12(9.2)$ & $14(10.8)$ & $11(8.5)$ & & $5(3.8)$ & $20(15.4)$ & $12(9.2)$ & \\
\hline \multicolumn{9}{|l|}{ Empowering } \\
\hline Low & $6(4.7)$ & $4(3.1)$ & $2(1.5)$ & 0.001 & $5(3.8)$ & $6(4.6)$ & $1(0.8)$ & $<0.0001$ \\
\hline Moderate & $25(19.2)$ & $29(22.3)$ & $12(9.3)$ & & $7(5.4)$ & $49(37.7)$ & $10(7.7)$ & \\
\hline High & $5(3.8)$ & 25 (19.2) & 22 (16.9) & & $0(0.0)$ & $23(17.7)$ & $29(22.3)$ & \\
\hline \multicolumn{9}{|l|}{ Enabling } \\
\hline Low & $3(2.3)$ & $4(3.0)$ & - & $<0.0001$ & $4(3.1)$ & $3(2.4)$ & - & $<0.0001$ \\
\hline Moderate & $22(16.9)$ & $9(6.9)$ & $4(3.0)$ & & $5(3.8)$ & $25(19.2)$ & $5(3.8)$ & \\
\hline High & $11(8.5)$ & $45(34.7)$ & $32(24.7)$ & & $3(2.3)$ & $50(38.5)$ & 35 (26.9) & \\
\hline \multicolumn{9}{|l|}{ Supporting } \\
\hline Low & $4(3.1)$ & $5(3.8)$ & - & $<0.0001$ & $6(4.6)$ & $3(2.3)$ & - & $<0.0001$ \\
\hline Moderate & $26(20.0)$ & $31(23.8)$ & $4(3.1)$ & & $6(4.6)$ & $47(36.2)$ & $8(6.2)$ & \\
\hline High & $6(4.6)$ & 22 (16.9) & $32(24.6)$ & & $0(0.0)$ & $28(21.5)$ & $32(24.6)$ & \\
\hline
\end{tabular}

of 28 questions which are also arranged on a Likert scale. The dependent variable of family commitment and ability in early detection of children's growth and development consists of 24 and 10 questions with a Likert scale and has been declared valid and reliable after going through questionnaire testing. Interpretation of scores to determine the assessment category is $<35$ for low, $35-78$ for moderate and 79 for high.

\section{Data Analysis}

The research data that had been tabulated were then analyzed using SPSS Version 21 . The results of the study were presented through descriptive analysis with a frequency distribution table and cross tabulation between variables. Analysis of the factors that affect commitment and ability to detect early childhood growth and development was carried out using bivariate statistical tests and multivariate logistic regression with a significance level of $p<0.05$. 
Nursalam., et al. (2021)

Table 3. Multivariate Analysis in Commitment and Ability of Mother to Detect Stunting

\begin{tabular}{|c|c|c|c|c|c|c|c|c|}
\hline \multirow[t]{3}{*}{ Variable } & \multicolumn{4}{|c|}{ Commitment in Early Detection } & \multicolumn{4}{|c|}{ Ability in Early Detection } \\
\hline & \multirow[t]{2}{*}{$\mathbf{P}$} & \multirow{2}{*}{$\begin{array}{c}\text { Exp } \\
\text { (B) }\end{array}$} & \multicolumn{2}{|c|}{$95 \% \mathrm{Cl}$} & \multirow[t]{2}{*}{$\mathbf{P}$} & \multirow[t]{2}{*}{$\operatorname{Exp}(B)$} & \multicolumn{2}{|c|}{$95 \% \mathrm{Cl}$} \\
\hline & & & Lower & Upper & & & Lower & Upper \\
\hline Family connectedness & 0.040 & 1.200 & 0.527 & 2.730 & 0.178 & 0.845 & 0.121 & 5.892 \\
\hline Community resources & 0.006 & 1.948 & 0.888 & 4.272 & 0.068 & 1.018 & 0.197 & 5.262 \\
\hline Competing role demand & 0.171 & 1.753 & 0.730 & 4.208 & 0.594 & 2.222 & 0.395 & 12.509 \\
\hline Empowering & 0.774 & 0.607 & 0.250 & 1.473 & $<0.0001$ & 3.328 & 0.603 & 18.363 \\
\hline Enabling & 0.251 & 1.222 & 0.489 & 3.058 & $<0.0001$ & 1.387 & 0.395 & 4.869 \\
\hline Supporting & 0.498 & 1.122 & 0.462 & 2.729 & $<0.0001$ & 11.827 & 1.757 & 79.610 \\
\hline
\end{tabular}

\section{Ethical Clearance}

This study has obtained the feasibility of an ethical clearance received by the Ethics Research Commission, Surabaya Health Polytechnic with the certificate number EA / 261 / KEPK-Poltekkes_Sby / $\mathrm{V} / 2020$. Voluntary respondent approval was carried out through online Google-based questionnaires. All respondents have agreed and are willing to participate in this study. The management of research ethics is carried out by evaluating proposals and research designs that have been made through the ethical principles of health research. The ethical review was carried out at the Faculty of Nursing, Airlangga University for one month and analyzed by reviewers who already have expertise in the field of research.

\section{Results}

Table 1 shows that the highest maternal age is 20 30 years old as much as $75.4 \%$ (98 respondents) with the highest education being senior high school as much as $52.3 \%$ (68 respondents). The most dominant occupation of mothers is as housewives as much as $81.5 \%$ (106 respondents) with the most occupations of husbands being civil servants as much as $80.6 \%$ (104 respondents), the most dominant income is under regional minimum as much as $82.2 \%$ (106 respondents). The maximum number of children was having 2 children as much as $38.5 \%$ (50 respondents), the highest age of children was 3 years as much as $55.4 \%$ (72 respondents) and the most frequent visits to public health center were always $90.0 \%$ (117 respondents).

Table 2 shows the cross tabulation of the factors that influence commitment at the age of 20-30 years showing moderate commitment as much as $34.6 \%$ (45 respondents), maternal education with secondary education level is $24.6 \%$ (32 respondents), housewives and fathers with jobs as civil servants also showed that their commitment was moderate. The number and age of the last child in each family indicated that the level of family commitment was also moderate. Families who always come to health facilities have a moderate level of commitment as much as $40.8 \%$ (53 respondents). In terms of family connectedness, community resources and the demands of a moderately competitive role, it shows that family commitment in early detection of stunting is also moderate. However, in families with a high level of support, the commitment to early detection of stunting is also high. (32 respondents). The most stunting detection ability is at the moderate level, high detection ability is shown in housewives aged $20-30$ years by $25.4 \%$ (33 respondents). Frequent visits to health facilities also did not result in high abilities, but their abilities were still moderate with $54.6 \%$ (71 respondents). Families with high community resources, the ability to detect early stunting also showed high results (19.2\%), as well as families with high support, enabling and reinforcing also showed high ability to detect stunting.

Table 3 shows the multivariate analysis with logistic regression on the variables that show the significant value of the bivariate analysis. Family commitment in early detection of stunting shows that the factor that has the greatest influence is community resources with a value of $p=0.006$; Exp (B) $=1,948 ; \mathrm{Cl} 95 \%=0.888-4.272$, this shows that community resources affect commitment 1-4 times compared to other variables. In the ability to detect early stunting, the most dominant factors are supporting, enabling and empowering. Supporting has a value of $p=0.000$; $\operatorname{Exp}(B)=11.827$; $C l 95 \%=$ 1.757-79.610, this shows that supporting affects the ability 1.7 - 79 times compared to other factors. Empowering also showed significant with $p=0.000$; $\operatorname{Exp}(B)=3.328 ; \mathrm{Cl} 95 \%=0.603-18.363$, this show that empowering affect ability $0.6-18$ times than other factors, it also showed in enabling variable that affect the ability $0.3-5$ times than other variables ( $p$ $=0.000 ; \operatorname{Exp}(B)=1.387 ; \mathrm{Cl} 95 \%=0.395-4.869)$.

\section{Discussion}

Family commitment in early detection of stunting showed that the factor that has the greatest influence was community resources, while on the ability to detect early stunting, the most dominant factors were supporting, empowering and enabling. Community resources could be used as reinforcement in increasing family commitment in early detection of stunting, because community involvement was the key to successful public health. The ability to detect early stunting shows that the most dominant factor is the support factor. The higher the support, the 
Analysis of Factors Affecting Commitment

higher the family's ability to take early detection measures. It is also supported by empowering and enabling factors, because caring for children requires the participation of parents and families to be given family empowerment to create the best environment in parenting. Enabling factors that come from outside the individual also play a major role in supporting and facilitating children's growth.

Several factors that cause stunting are the poor ability of families to care for children, the lack of knowledge of mothers in maintaining health and nutrition before and during pregnancy (Fajrianti et al., 2020), and after childbirth (Utami, Susilaningrum, \& Nursalam, 2019). The availability of health services is still limited, especially in remote areas, including pregnancy check-up, so that during pregnancy and childbirth, mothers do not get maximum health services (Krisnana, Pratiwi, \& Cahyadi, 2020; Utami, Susilaningrum, Taufiqurrahman, et al., 2019). Initial knowledge also shows a lack of quality, so that what mothers know is also limited in consuming nutritious food, doing activities during pregnancy, taking vitamins, resting, managing stress and routine pregnancy check-ups. This will not happen and can be prevented if community involvement and support are also high. Community involvement is an important role of public health programs (Howard et al., 2018; Lestari et al., 2018).

Many programs in managing stunting have become the main focus in the success of health planning (Susilaningrum, Utami, Taufiqurrahman, \& Nursalam, 2020). What needs to be improved so that the program can be implemented more effectively in reducing stunting is to collect data in an integrated manner through tiered community involvement (Primasari \& Keliat, 2020; Titaley et al., 2019). This is consistent with research which states that stunting can be resolved by regular monitoring of pregnant women and families who are detected to be experiencing nutritious food deficiencies (Damanik \& Wanda, 2019; Husaini et al., 2018). Other research also states that the role of all sectors of society is the main key to solving stunting.

The main problem of stunting is that during the 1000 days of the baby's life, during which time there must be regular monitoring to prevent the condition of malnutrition that gets worse in the baby (Andersen et al., 2016). Based on the feeding pattern, it can be seen that the incidence of stunting mostly shows that the toddlers are not getting good feeding patterns (Soekatri et al., 2020). This poor feeding can stem from a lack of family knowledge, unavailability of nutritious food, lack of involvement in the public health sector, access to health services and various other problems (Rahayu, Yulidasari, Khairiyati, Rahman, \& Anhar, 2016; Susilaningrum et al., 2018). The results of this study are in line with the research which states that the pattern of care for feeding is one of the risk factors for stunting, this is because the monotonous daily diet does not vary and the mother's lack of knowledge in fulfilling child nutrition is the most decisive thing (Utami,
Susilaningrum, \& Nursalam, 2019). The results of other studies also state that the supervision of the various parties involved can affect the behavior of the mother, the mother will tend to be more motivated if there are many support systems found in parenting the child. This will cause food intake for toddlers to be less, both in terms of quality and quantity so that they are prone to stunting (Krisnana et al., 2020).

During the study, researchers also found several limitations. Researchers needed to evaluate the factors that influence commitment and willingness to self-detect stunting in families with disease, so that differences can be identified in families with children with normal growth and development. Families with children at risk and families with children who are already categorized as stunting, so that the bias is used as a reference in providing health interventions to deal with stunting.

\section{Conclusion}

Stunting is a problem in public health and the global problem in sustainable development goals, stunting is still the main focus of the government in maternal and child health. The main factor affecting family commitment is community resources and the main factor in the willingness to early detection is support, both support from family, community and all parties involved in handling stunting. Commitment and willingness behavior in early detection of stunting in children is an important role that every parent must have with the full support of the family. It can be concluded that the role of family especially parents in parenting their children can prevent stunting. This study has benefits in public health that has been proven through the dominant factors that affect the ability and commitment of the family.

\section{Declaration conflict of interest}

This manuscript does not have any conflict of interest with anyone and the authors of this study also do not have any conflict of interest.

\section{Acknowledgment}

The authors state to thank you to all respondents that voluntary filled out the questionnaire, we also thank to all families with children aged $0-72$ months in the area of the Public Health Center in Surabaya City. Special mention for the Surabaya Health Polytechnic of Surabaya that gives the funding and facilitate this research.

\section{Funding}

The authors received funding from Surabaya Health Polytechnic of Surabaya Grant for the period of 2020-2021.

\section{Authors' Contribution}

This study involves all research members. SU has the job to concept the research idea and organize the job description of every member, she also prepares the research methods and procedure. RS prepares 
the research instrument, ethical submission and organizes the research. NN is a supervisor of this research. NN reviews and revises all the manuscript and research data after research finished.

\section{Data Availability Statement}

This research study has completed data saved by the authors and the authors just present the important data that was suitable for this research. If the reader needs to share the data, they can get more information from corresponding author

\section{References}

Alkaff, F. F., Flynn, J., Sukmajaya, W. P., \& Salamah, S. (2020). Comparison of WHO growth standard and national Indonesian growth reference in determining prevalence and determinants of stunting and underweight in children under five: A cross-sectional study from Musi sub-district. F1000Research, 9. https://doi.org/10.12688/ f1000research.23156.2

Andersen, C. T., Stein, A. D., Reynolds, S. A., Behrman, J. R., Crookston, B. T., Dearden, K. A., ... Fernald, L. C. H. (2016). Stunting in infancy is associated with decreased risk of high body mass index for age at 8 and 12 years of age. Journal of Nutrition. 146(11), 22962303. https://doi.org/10.3945/jn.116.234633

Beal, T., Tumilowicz, A., Sutrisna, A., Izwardy, D., \& Neufeld, L. M. (2018). A review of child stunting determinants in Indonesia. Maternal \& Child Nutrition, 14(4), e12617. https://doi. org/10.1111/mcn.12617

Curry, G. (2018). Stunted growth: the early development of football in Derby and South Derbyshire. Soccer and Society, 19(1), 24-34. https://doi.org/10.1080/14660970.2016.12762 41

Damanik, S. M., \& Wanda, D. (2019). The influence of feeding practice on the risk of stunting in infant and young children in developing countries: $A$ literature review. IImu Gizi Indonesia, 3(1), 1322. https://doi.org/10.35842/ilgi.v3i1.117

Fajrianti, D., Yunitasari, E., \& Pradanie, R. (2020). The Correlation Between Personal Reference: Health Workers and Health Facilities with Parenting in Stunting Prevention. Pediomaternal Nursing Journal, 6(2), 125-132. https://doi.org/10.20473/pmnj.v6i2.20966

Goldin, S. N., \& Papaioannou, V. E. (2003). Unusual misregulation of RNA splicing caused by insertion of a transposable element into the $T$ (Brachyury) locus. BMC Genomics, 4. https:// doi.org/10.1186/1471-2164-4-14

Howard, S. C., Zaidi, A., Cao, X., Weil, O., Bey, P., Patte, C., ... Moreira, C. (2018). The My Child Matters programme: effect of public-private partnerships on paediatric cancer care in lowincome and middle-income countries. The Lancet Oncology, 19(5), e252-e266. https:// doi.org/10.1016/S1470-2045(18)30123-2
Husaini, Marlinae, L., Setyaningrum, R., Rosadi, D., Wulandari, A., Ulfah, N., \& Hastaniah. (2018). Analysis of factors affecting stunting events in underwrapped in cempaka velocity mining area kota banjarbaru in year 2017. Indian Journal of Public Health Research and Development, 9(7), 85-89. https://doi.org/10.5958/09765506.2018.00618.6

Izza, N., Purnomo, W., \& Mahmudah. (2019). Factors affecting the occurrence of stunting in indonesia. Indian Journal of Public Health Research and Development, 10(10), 1845-1850. https://doi.org/10.5958/09765506.2019 .03114 .0

Krisnana, I., Pratiwi, I. N., \& Cahyadi, A. (2020). The relationship between socio-economic factors and parenting styles with the incidence of stunting in children. Systematic Reviews in Pharmacy, 11(5), 738-743. https://doi. org/10.31838/srp.2020.5.106

Langi, L. A. (2020). Clean and healthy living behavior with the stunting events in children in central Java, Indonesia. Systematic Reviews in Pharmacy, 11(12), 127-133. https://doi. org/10.31838/srp.2020.12.21

Leroy, J. L., \& Frongillo, E. A. (2019). Perspective: What Does Stunting Really Mean? A Critical Review of the Evidence. Advances in Nutrition, 10(2), 196-204. https://doi.org/10.1093/ advances/nmy 101

Lestari, S., Fujiati, I. I., Keumalasari, D., \& Daulay, M. (2018). The prevalence and risk factors of stunting among primary school children in North Sumatera, Indonesia. IOP Conference Series: Earth and Environmental Science, 125(1), 12219. https://doi.org/10.1088/17551315/125/1/012219

Nelly SD Situmeang, Etti Sudaryati, \& Jumirah. (2020). Correlation of parenting and nutrient intake with stunting in children 24-59 months. Britain International of Exact Sciences (BloEx) Journal, 2(1), 280-285. https://doi. org/10.33258/bioex.v2i1.147

Pertiwi, M. R., Lestari, P., \& Ulfiana, E. (2019). Relationship between parenting style and perceived information sources with stunting. International Journal of Nursing and Health Services, 2(4), 273-279. https://doi. org/10.35654/ijnhs.v2i4.150

Pradnyawati, L. G., Kartinawati, K. T., \& Ratna Juwati, D. A. P. (2019). Parenting pattern of feeding in stunting toddlers at the working area of Tegallalang I Primary Health Centre. Journal of Community Empowerment for Health, 2(2). https://doi.org/10.22146/jcoemph.47019

Primasari, Y., \& Anna Keliat, B. (2020). Parenting practices as an effort to prevent the impact of stunting on children's psychosocial development. Jurnal IImu Keperawatan Jiwa, 3(3), 263-272. https://doi.org/10.32584/jikj. v3i3.609

Rahayu, A., Yulidasari, F., Khairiyati, L., Rahman, 
F., \& Anhar, V. Y. (2016). The risk factor of mother's nutrition knowledge level related to stunting in public health center region Cempaka, Banjarbaru City. International Journal of Applied Business and Economic Research, 14(10), 6999-7008. Retrieved June 06, 2021, from https://serialsjournals.com/ abstract/15578_ch-54.pdf

Rizal, M. F., \& van Doorslaer, E. (2019). Explaining the fall of socioeconomic inequality in childhood stunting in Indonesia. SSM Population Health, 9. https://doi.org/10.1016/j. ssmph.2019.100469

Ryadinency, R., N, S., \& Patmawati, T. A. (2020). Analysis of determinant factors in stunting children in Palopo, Indonesia. Journal Wetenskap Health, 1(2), 77-82. https://doi. org/10.48173/jwh.v1i2.39

Soekatri, M. Y. E., Sandjaja, S., \& Syauqy, A. (2020). Stunting was associated with reported morbidity, parental education and socioeconomic status in 0.5-12-year-old Indonesian children. International Journal of Environmental Research and Public Health, 17(17), 1-9. https://doi.org/10.3390/ ijerph17176204

Susilaningrum, R., Utami, S., Nursalam, N., \& Tristiana, R. D. (2018). Analysis of factors related to behavior cognition and effects on pregnant women in maternal and child health (Mch) handbook utilisation. Indian Journal of Public Health Research and Development, 9(11), 492-497. https://doi.org/10.5958/09765506.2018 .01504 .8
Susilaningrum, R., Utami, S., Taufiqurrahman, T., \& Nursalam, N. (2020). Development of interprofessional collaboration model to manage stunting in toddler. International Journal of Psychological Rehabilitation, 24(7), 7494-7502. https://doi.org/10.37200/IJPR/ V24I7/PR2700717

Titaley, C. R., Ariawan, I., Hapsari, D., Muasyaroh, A., \& Dibley, M. J. (2019). Determinants of the stunting of children under two years old in Indonesia: A multilevel analysis of the 2013 Indonesia basic health survey. Nutrients, 11(5). https://doi.org/10.3390/nu11051106

Utami, R. A., Setiawan, A., \& Fitriyani, P. (2019). Identifying causal risk factors for stunting in children under five years of age in South Jakarta, Indonesia. Enfermeria Clinica, 29(2), 606-611. https://doi.org/10.1016/j. enfcli.2019.04.093

Utami, S., Susilaningrum, R., \& Nursalam. (2019). The effect of health promotion based on the health promotion model with a peer group approach regarding the utilization of maternal and child health handbook. Indian Journal of Public Health Research and Development, 10(10), 1987-1992. https://doi. org/10.5958/0976-5506.2019.03139.5

Utami, S., Susilaningrum, R., Taufiqurrahman, \& Nursalam. (2019). Factors associated with interprofessional collaboration for handling stunting in children. Journal of Global Pharma Technology, 11(8), 262-267. Retrieved June 03, 2021, from http://www.jgpt.co.in/index.php/ jgpt/article/view/2863/2315 